\title{
'The Girl Effect': Exploring Narratives of Gendered Impacts and Opportunities in Neoliberal Development
}

\author{
by Farzana Shain Keele University
}

Sociological Research Online, 18 (2) 9

http://www.socresonline.org.uk/18/2/9.html

To cite: Shain, F. (2013). 'The girl effect': Exploring narratives of gendered impacts and opportunities in neoliberal development. Sociological Research Online, 18(2), 181-191.

10.5153 / sro.2962

Received: 19 Sep 2012 Accepted: 5 Mar 2013 Published: 31 May 2013

\begin{abstract}
This paper explores representations of girls in current discourses of neoliberal development through an analysis of a range of texts that promote the global Girl Effect movement. These representations are situated in the context of theoretical debates about gender mainstreaming and policy developments that construct girls and women's 'empowerment' as 'smart economics'. The paper draws on postcolonial and transnational feminist analyses that critique market-led approaches to development and their complicities in the dynamics of neo-colonialism and uneven development, to contextualise the Girl Effect movement. It is argued that the Girl Effect movement draws on colonial stereotypes of girls as sexually and culturally constrained, but reworks these through the discourses of neoliberal development to construct girls as good investment potential. In doing so, it reproduces a dominant narrative that highlights the cultural causes of poverty but obscures structural relations of exploitation and privilege.
\end{abstract}


Keywords: Girls, gender, neoliberalism, World Bank, Girl Effect, neoliberal development

\section{Introduction}

Within narratives of international development, girls are currently constructed as the powerful and privileged agents of social change, indeed even as the solutions to the global crisis and world poverty. In the last two decades, girls in the global North 1 have emerged across a range of social and cultural spaces as subjects worthy of investment (McRobbie 2009: 57-8). In the UK for example, feminist research has highlighted how, girls, because of their apparent educational success and their propensity for hard work, are instrumentalised as 'ideal' neoliberal subjects. The academic success of predominantly white middle class girls, relative to boys, has also been proclaimed as evidence of meritocracy at work (Francis \& Skelton 2008; Jackson et al. 2010; Ringrose 2012). References to girls in the global South continue to be framed through discourses of development, but, where girls and women from the global South were once dismissed by development strategists as merely wealth consumers rather than wealth producers (Eyben \& Napier-Moore 2008), they are now offered up, not only as significant investment potential but also as solutions to the present global crisis (World Bank 2007) and world poverty (see coalitionforadolescentgirls.org and girleffect.org). In his keynote address at the World Bank Group's celebration of International Women's Day in March 2009, President of the Bank, Robert Zoellick, advised staff-to pay special attention to gender equality in the midst of the current economic crisis within their development work. Zoellick has also earlier proclaimed that women can be the agents of change and that 'Investing in adolescent girls is precisely the catalyst poor countries need to break intergenerational poverty and to create a better distribution of 
income. Investing in them is not only fair, it is a smart economic move' (World Bank 2008).

One of the reasons for the current public and policy prominence of girls in the global South arises from a vast body of research commissioned by international development agencies to measure progress against indicators of poverty. The overall messages of the knowledge emanating from this body of work in recent years, includes that girls and women make up around $70 \%$ of the world's poorest billion (Chant 2006), but also, that compared to men, women work more efficiently, invest more of their income in their families and are better at paying back loans when they get them. This 'evidence-based' knowledge is encapsulated in the World Bank's catchphrase of gender equality as 'smart economics' (World Bank 2006). Gender has not only found its way into mainstream policy discourse and practice in development agencies globally but is also now one of the strategic priorities of the United Nations (Millennium Development Goal (MDG)) Goal 3 'to promote gender equality and empower women') to be achieved by 2015 . And, in 2012, the World Bank, for the first time devoted its flagship publication, the annual World Development Report (WDR) to the theme of gender equality (World Bank 2012).

The 'mainstreaming of gender equality' and the explosion of policy and development interest in girls, need to be located in the context of two significant and interlinked developments that have an impact on how girls and girlhood are currently constructed in development discourse: first, the advancement of women and their positioning as key players in the global economic market has coincided with the weakening of feminism and the women's movement, with the antiglobalisation movement now cited as the most significant site for transnational feminist organisation (Mohanty 2002; McRobbie 2009) - this raises questions about the ideological bases of the empowerment models that are currently being advanced by 
international development organisations and the extent to which neoliberal development agencies can deliver on the gender agenda; second, girls and gender have gained a new policy and public visibility 'at a time when neoliberal and globally restructuring processes entrench impoverishment and gendered/racialised/nationalist/religious difference in practice at the core of their accumulation projects' (Radcliffe 2006: 524). In the last decade, feminist postcolonialist and Marxist analyses have problematised market-led approaches to development and their complicities in the dynamics of neo-colonialism and uneven development (Rankin 2001; Roy 2007, 2010; Harvey 2011). In particular, the instrumentalisation of poor people for economic gain through the processes and practices of microfinance have been criticised widely for advancing neoliberal economic globalization at the same time as exacerbating and deepening existing poverty and inequalities. As David Harvey (2011) argues, the purported aims of microfinance schemes which offer small amounts of credit to collectives, usually involving small groups of poor rural women, are 'to permit the population to raise themselves out of poverty and join the merry business of capital accumulation. Some succeed, but for the rest it means debt peonage' (2011: 146).

It is against this background that this paper analyses the current representation of girls in neoliberal discourses of development. Taking the global Girl Effect campaign as a case in point, I explore the notions of empowerment and agency that are embedded in the representations of girls and girlhood in the campaign materials promoted by the Girl Effect movement. The Girl Effect website alongside the first Girl Effect video and the globalgiving.com Girl Effect fund was officially launched by the Nike Foundation in partnership with the NoVo Foundation in 2008. Like other 'girl focussed' global campaigns such as Plan International's 'Because I am a Girl', the Girl Effect urges potential donors and investors - 
including ordinary citizens as well as transnational corporations and nongovernmental organisations - to see the potential of girls and to invest in them. The Girl Effect is so-named because it is based on the claim that when given the opportunity, women and girls are more effective at lifting themselves and their families out of-poverty, thereby having a multiplier effect within their villages, cities, and nations. Within current neoliberal development discourse, girls are being represented as entrepreneurial subjects whose integration into the formalised financial systems of global capitalism can facilitate and expedite their escape from poverty. But this claim needs to be read in the context of the wealth of evidence (for example, International Labour Office and United Nations reports over the last decade) and analysis (Peck \& Tickell 2002; Jessop 2002; Harvey 2005; Amin 2010) that has reviewed the effects of neoliberal economic globalisation. These analyses point to a slowdown in economic growth and increased levels of inequality and poverty, especially in sub Saharan Africa. Countries displaying the greatest levels of growth and decreased levels of poverty - measured in terms of the number of people living under $\$ 1.00$ per day - such as China, did not follow neoliberal economic policies.

There is still relatively little research on the impact of initiatives such as the Girl Effect on girls in the global South (though see Hayhurst (2011) for an evaluation of one Sport and Gender Girl Effect funded project in Eastern Uganda). My aim in the current paper is not to evaluate the initiatives that form part of the Girl Effect movement but to analyse the representations of girls by the global Girl Effect campaign, for their continuities with and reworking of colonial stereotypes. I combine this reading of representation with an analysis of World Bank texts including World Bank statements in order to locate these representations in the context of the discourses of neoliberal development. I draw on the term neoliberal development to refer to the current model of 
international development that is underpinned by neoliberal ideology and strategies. As Brenner and Theodore (2002: 349) note, 'the linchpin of neoliberal ideology is the belief that open, competitive, and unregulated markets, liberated from all forms of state interference, represent the optimal mechanism for economic development'. The neoliberalisation of development since the 1970s has involved the global imposition of a neoliberal agenda but this has been uneven in terms of geographical spread, its institutional forms and as Brenner and Theodore (2002) note, 'its sociopolitical consequences have varied significantly across spatial scales and among each of the major supraregional zones of the world economy'.

I argue that the dominant messages emanating from current neoliberal development texts serve to reproduce contradictory representations of girls as capable and hardworking but culturally constrained; as agentic but still dependent and in need of assistance from donors and investors. These contradictory representations position girls as good investment potential - as untapped resources for global capitalism at a time of renewed crisis. By inviting the viewer as potential donor or investor to 'save' girls from a fate of poverty, the texts invoke a sense of agency in the ordinary citizen who chooses to donate or invest in the 'poor girl'. In the process, they reinforce colonial notions of civilising and saving the racialised Other. In highlighting the cultural causes of poverty, current representations of girls in development literature also shift attention from the historical and contemporary structural causes of inequalities and relations of exploitation and privilege. The paper is divided into three main sections: the first outlines the policy context in which the shift from 'development' to 'poverty alleviation' can be read as a reworking of colonialism, the second section explores the genesis of 'smart economics' as a new neoliberal discourse that serves to highlight girls' and women's propensity for work as good 
for the economy; the third section outlines and analyses how girls and girlhood are currently represented across a range of promotional texts connected with the global Girl Effect movement

The re-making of development: Development, neoliberalism and neo-colonialism

Development, as both a field and a concept, is as contested now as it was in its previous incarnation as colonialism (Escobar 2010).

Postcolonial analyses highlight that while powerful nations may have vacated their former geographical colonies in Africa and Asia, 'they retained them not only as markets but as locales on the ideological map over which they continued to rule morally and intellectually' (Said 1993: 25). The field of development therefore constitutes an important battleground for cultural ideas, political manoeuvrings and policies and since the 1970s, for a project of Western-centric neoliberal governance (Amin 2010). It is characterised by a multitude of actors, interests and agendas and the sometimes clashing but mostly coexisting, of benevolent liberalism and brutal expansionist agendas. Although a range of aid agencies including Nongovernmental Organisations (NGOs) and Multinational Corporations (MNC) now proliferate the field of development, the World Bank and the International Monetary Fund (IMF) are recognised as key players in agenda setting for development since their inception at the Bretton Woods conference in 1944.

There has been much debate and discussion about development's current focus (since the 1990s) on 'poverty reduction' or 'poverty alleviation' and 'good governance' - and the extent to which this signals a shift away from earlier 1980s- neoliberal policies of structural adjustment, privatization and the downsizing of the state. The new emphasis on empowering and securing the poor through basic service delivery and decentralisation - with the state as local partner to development agencies and transnational corporations - 
apparently marks a decisive break with the past and a whole set of new development possibilities including political freedom and social justice (Stiglitz 1998; Sen 1999). However, this is a much contested claim as I discuss below.

As Roy (2010: 6) notes, poverty is not a new phenomenon but the how, when and why of poverty as a catalyst of social change reveals the embeddedness of different conceptions of poverty in governance structures over the last half century. In the post 1944 period, poverty was recognised as a problem of national economy and it management, and development was conceptualised as a ladder with some countries being 'more developed' than others. There are currently a range of perspectives on the World Bank's role in development since it declared poverty to be one of its top priorities in 1990 (World Bank 1990).

According to Roy (2010), the new ambitious goals set in 1990 for poverty alleviation via the Millennium Development Goals represent a 'kinder, gentler process' of development concerned with economic growth. This contrasts with the 1980s, when conservative regimes across the Atlantic largely conceptualised poverty as a problem of the dependent and undeserving poor, rather than the result of structural inequalities and the uneven development of national economies. For Roy, with the turn of the century, a new development approach has taken shape that she refers to as 'Millennial Development'. Poverty has become a global conscience issue and the discourse has shifted from 'modernization' of national economies to the 'alleviation' of the poverty of the 'bottom billion' the 1.4 billion living on less than $\$ 2$ a day.

Boas and McNeill (2003) suggest that the World Bank is 'paradoxically' now, 'both a bastion of neoliberalism and a quite progressive development institution concerned with local participation and needs' (cited in Cammack 2004:193). However, 
Cammack (2004) from a Marxist perspective argues that despite tensions and contradictions inherent within the World Bank (notably the fallout from World Bank Chief Economist Stiglitz's critique of the IMF during the late 1990s), the goal of providing basic services to the poor has consistently been argued by the Bank to be subordinate to the dominant goal of increasing the productivity of labour. Citing World Bank statements about the need to harness the labour of the poor for production, Cammack (2004: 192) argues that the instrumentalisation of the poor for economic gain is 'a strategy for the global mobilisation of productive labour of the poor'. Rather than a break with the earlier version of neoliberal development, this represents according to Cammack, a 'familiar neoliberal policy package of liberalisation and privatisation' (2004). He further argues that through its various statements, the Bank has consistently justified the establishment of a macroeconomic framework (a competitive environment within which enterprise could flourish; the integration of economies into the global economy; and 'investment in people' to supplement the market in the areas of education, health, nutrition and family planning) which would be supported by microeconomic discipline. That is,

'the World Bank's antipoverty programme, far from being a shift away from the neoliberal revolution, was a means to completing it. It envisages a global proletariat, on a wage of two dollars a day, with a reserve army of labour acting as a disciplinary force ...it represented a deep neoliberalism, in contrast to the 'shallow' neoliberalism reflected in the idea of a minimal state and a commitment to deregulation without simultaneous attention to the reshaping of social relations and institutions to make markets competitive (2004: 192).

Looking forward a decade, from the WDR 1990 to the WDR 2000/1, Cornwall and Brock note several discursive shifts in the World Bank's approach to 'poverty alleviation', including the acquisition of a moral 
tone, with liberal references to 'poor people', a redefinition of poverty as a multifaceted problem and the shift to a coordinated partnership of aid - with the state reinstated as a 'partner' in the enterprise, with whom external development actors conduct 'policy dialogue' in the new language of euphemism (Cornwall \& Brock 2005). However as Cammack argues, the analytical framework for the governance of global poverty was already in place in the 1990s. The 1994 WDR, Infrastructure for Development laid the framework for competition which included strategic partnerships, including with the state and the pivotal role of Education as critical for economic growth and poverty:

The World Bank's strategy for reducing poverty focuses on promoting the productive use of labor-the main asset of the poorand providing basic social services to the poor. Investment in education contributes to the accumulation of human capital, which is essential for higher incomes and sustained economic growth. Education-especially basic (primary and lower secondary) educationhelps reduce poverty by increasing the productivity of the poor, by reducing fertility and improving health, and by equipping people with the skills they need to participate fully in the economy and in society. More generally, education helps strengthen civil institutions and build national capacity and good governance-critical elements in the implementation of sound economic and social policies. (World Bank 1995, cited in Cammack 2004: 193)

Cammack's analysis focuses on the proletarianisation of the poor as a major objective of neoliberal development in the 1990s. However, feminists have pointed out how the 'feminisation' of that labour has been a central preoccupation of development since the 1980s with women's resilience to the fall out of Structural Adjustment Policies (for example, their ability to save more efficiently in the face of rising unemployment) being constructed as good for development (Elson 1991; Mosedale 2005; Chant 2012). As Rankin notes 
(2001:19), the 'prevailing neoliberal orthodoxy has a distinctly feminised character as development institutions target women and girls as the desired beneficiaries and agents of progress'. As I discuss in the next section, the discourse of gender equality as 'smart economics' - that is, the notion that investment in girls and women is a necessary pre-cursor for their empowerment and good for development - was first formally introduced in the Bank's 'Gender Action Plan' (World Bank 2006). It represents the absorption by neoliberal development agencies of decades of feminist research highlighting the capacity of women to carry the burden of societal change. The discourse is firmly enshrined in WDR, 2012, Gender Equality and makes a case for a 'feminisation of policy' through calls for the harnessing of the skills, labour and attributes of girls and women to entrepreneurial work.

\section{Gender equality as 'smart economics': changing conceptions of empowerment and agency in development}

Postcolonial and feminist theorising has had an extensive impact on how development has been conceptualised both academically and in the thinking and practice of international development agencies (Marchand 2009). In the 1970s, Women in Development (WID) was the dominant framework for analysing the role and significance of gender in development. Its emergence challenged a seemingly universal 'male bias' in development programmes (Chant \& Gutmann 2002). With its focus on women, rather than gender, it sought to highlight the potential positive synergies between investing in women and beneficial economic growth. This emphasis rested on efficiency arguments like those embedded in contemporary development discourse - that construct women as agents for development. Talk of efficiency was a WID political strategy to foster the inclusion of women's issues in development policies that met with some limited success. More problematic was the failure of WID to challenge class, gender and racialised hierarchies among women; 
this effectively meant that a white Western feminist perspective was privileged in gendered development talk (Mohanty 1988). While early WID interventions encouraged a shift of emphasis from reproductive to productive activities, they failed to challenge the racialised population control policies, which drew on the pathologisation of the sexuality of women in the global South (Wilson 2011).

In the 1980s, WID gave way to the new approach now known as Gender and Development (GAD) and a recognition that the empowerment of women needed to occur at a grassroots level. However, as postcolonialist feminists highlighted, the emphasis remained firmly on women in the global South, being GIVEN power (Kabeer 1994; Spivak 1999; Mohanty 1988, 2002). Overall, GAD also failed to challenge the colonial and neo-colonial underpinnings of the relations between so-called Western and Third World feminists. Since the 1980s feminist activists and academics have been concerned to show how the social construction of gender relations interacts with all forms of imperialism to shape the dominant ideologies of development (Marchand 2009). The issue of how empowerment and agency 'get done' in and through development has been a centrepiece for GAD debate and discussion since then (Eyben \& Napier-Moore 2009). Some feminists have argued that if women successfully access the opportunities presented through development, then patriarchal power structures will potentially be challenged (Kabeer 2003). Others (Spivak 1999, 2002) have questioned whether the forms of pedagogy advocated within neoliberal aid programmes can offer genuine empowerment especially when the education the girls will receive is likely to be saturated by the values of neoliberalised global capitalism (Spivak 2002; McRobbie 2009).

The publication of the World Development Report (2012) on Gender equality marked an important watershed for gender and 
international development. Gender was selected as the frame for analysing progress and development needs for the first time in the thirty year history of the WDR. Focusing on three key dimensions of gender equality: gender differences in education and health; voice, or decision-making authority in households and society; and access to economic opportunities, the WDR 2012 reports a narrowing of gender gaps in education, health and labour in the past 25 years. There is also a recognition that economic growth does not always lead to gender equality (Bedford 2012: 1). However, the Bank advances a focus on gender equality as 'smart economics' originally put forward in its Gender Action Plan (GAP) in 2007. In doing so, the Bank makes the business case for promoting women's empowerment, which frames current representations of girls and women as investment potential. The core message about gender equality as 'smart economics' is summarised in following way in the WDR:

Gender equality matters for development-it is smart economics.

Gender equality matters also as an instrument for development. As this Report shows, gender equality is smart economics: it can enhance economic efficiency and improve other development outcomes in three ways. First, removing barriers that prevent women from having the same access as men to education, economic opportunities, and productive inputs can generate broad productivity gains-gains all the more important in a more competitive and globalized world. Second, improving women's absolute and relative status feeds many other development outcomes, including those for their children. Third, levelling the playing field-where women and men have equal chances to become socially and politically active, make decisions, and shape policies-is likely to lead over time to more representative, and more inclusive, 
institutions and policy choices and thus to a better development path. (World Bank 2012: 3)

Although the Bank's stated aim is to escalate progress in terms of meeting the Millennium Development Goal 3 on gender equality and women's empowerment, as the above paragraph shows, gender equality remains an 'instrument for development'. It is a focus for the Bank because it can 'enhance economic efficiency', effect productivity gains and contribute to a 'competitive and globalized world'. While the report acknowledges gender gaps in education, and health, and argues the need for women's social and political empowerment, the latter is secondary to the main goal of economic empowerment. It is only through their economic empowerment that girls and women can 'become socially and politically active, make decisions and shape policies'. This in turn will lead to more representative and more inclusive institutions. So, the economic empowerment of women as individual workers or entrepreneurs is a necessary pre-condition for their social and political participation to other indicators of well-being. The business case for gender equality is thus made as women's empowerment is constructed as good for the economy, and agency which is defined as 'the ability to make choices to achieve desired outcomes' is said to be measurable by 'Whether and how much voice a woman has in household decision making over patterns of spending, including spending on children' and 'Women's ability to own, control, and dispose of property' which 'still differs from that of men-sometimes legally, often in practice' (World Bank 2012: 41-42).

Empowerment is a much contested, multifaceted and relational concept which, as stated earlier, has been the subject of feminist debate since the mid 1980s. However, the WDR's definition is a far cry from the notion of empowerment that was taken up by feminists, especially those from the 'Third World', in the 1970s and 1980s. The latter explicitly framed the feminist project as a struggle 
for social justice and equality between men and women. This was to be achieved by means of the transformation of economic, social and political structures at national and international levels. However, since the 1990s, empowerment has increasingly been taken up (mainstreamed) by international development agencies such as the World Bank to promote strategies focused on 'enlarging the choices and productivity of individual women, for the most part, in isolation from a feminist agenda and in the context of a withdrawal of state responsibility for broad-based economic and social support' (Bisnath 2001, cited in Mosedale 2005).

\section{Gender mainstreaming}

The concept of gender mainstreaming emerged in the early 1990s, initially sparked by a productive and lively debate among transnational feminists. This was prompted in large part by Mohanty's (1988) sharp critique of a Western feminist perspective that had the effect of essentialising 'Third World' women as lacking in agency since they were assumed to be universally oppressed by 'their men'. From the vantage point of this Western feminist perspective, 'Third World' girls and women were in need of empowerment from Western feminists.

The Fourth World Conference on Women in Beijing in 1995 marked an important turning point for feminism establishing a Global Platform for Action to work on women's empowerment. Mainstreaming gender required the development and evaluation of policy processes 'in order to incorporate a gender equality perspective' (Council of Europe 1998: 203). However, gender mainstreaming remains a contested concept.

Proponents including the British feminist Sylvia Walby (2002, 2005) proclaim that the adoption of gender mainstreaming by agencies of global governance, including the establishment of gender 
Millennium Development Goals, represents the success of gender mainstreaming. It is characterised as not simply an attempt at getting women included in policy but as a strategy for achieving gender equality (albeit through a slow progress model) through the adoption of macroeconomic and social policies which place gender specific state policies in relation to employment, reproductive health and education.

However, critics of gender mainstreaming argue that it lends itself to a neoliberal reorganisation strategy that seeks to optimise gender specific human resources for economic gain (Frey et al. 2006: 13; McRobbie 2009). That is, the assumption that 'women and younger women in particular, produce added value by virtue of their particular skills and competencies, which are now, in the age of the service, more in demand than in the past' (McRobbie 2009: 57). For McRobbie, gender mainstreamers advocate a path that may have some equalising potential, but which in essence is easily absorbed as a non-conflictual accommodating programme, by the structures and institutions of capitalism. McRobbie goes further in arguing that the incorporation by global governance agencies, of feminist policy experts, such as Walby who works for the United Nations, through gender mainstreaming, has led to a shift in emphasis from a focus on women to gender, and from women's rights to human rights. In doing so, gender mainstreaming has been a major player in the 'undoing' of a grassroots feminist project. Neoliberal governance organisations have effectively taken up the feminist project capturing its justice-based concepts such as empowerment and economising them, so that girls become noticeable for their potential to yield economic growth through efficiencies.

This shift in emphasis from women's to gender issues (and one might argue from women's to girls as the focus of neoliberal development) is argued to have taken the 'political bite' out of the term gender mainstreaming, leading to calls for revisiting the 
gender agenda (Ferguson 2010; Sardenberg 2007; Batliwala \& Dhanraj 2004; Woodford-Berger 2004). Others argue that the pragmatic feminism operated by agencies like the World Bank means that gender as a concept has gained common-sense status in development policy but there is little critical reflection as to how it is conceptualized, implemented and evaluated. The WDR 2012 on Gender equality, for example, is commended for including the work of feminists but for failing to properly to understand feminism. Bedford (2012) argues that the WDR report:

sidesteps crucial debates about whether free market reforms harm people in deep, sustained ways. It ignores that many people experience their employment as disempowering; that discrimination can be immensely profitable; that exploitation within markets-has significant advantages over-exclusion from markets-as a way to understand inequality; and that the private sector can fiercely resist gender equality measures since they incur costs.'

Although the report is recognised as offering a nuanced analysis of the issues, it ultimately embeds a business case for gender quality and empowerment as entrepreneurial individualised subjectivity. This is epitomised in the report's cover image which features the silhouette of a young African woman who could be aged anywhere between 15 and 30, confidently striding across a vast landscape which gives the impression of a desert. She is barefoot but holds a clutch purse. The image contrasts sharply with established and familiar representations of women in development texts: famine, hunger, disease, overcrowding. There are no babies, nor family or other members of the community visible in the picture. Instead the image of a lone, high headed girl 'on her way to somewhere', connects with a whole range of visual representations in current development campaigns that promote a particular individualised neoliberal conception of agency and empowerment that I discuss in the next section. 


\section{The 'girl effect': even smarter economics?}

Girls have until recently been invisible in development discourses, or marginalised as the sexless dehumanised symbols of poverty, crisis and famine. In part this is linked to the dominance of human rights paradigm which feminists have argued has tended to be male or boy centred in practice. In the last decade, however, girls and women have come to occupy a central place as subjects, objects and conceptualisers of development (Escobar 2010: x). 'Poverty ends with her'; 'Invest in a girl and she do the rest'; 'The most powerful force of change on the planet is a girl' are some of the catchphrases that have entered into common sense as a result of the global Girl Effect campaign. Initiated by the Nike Foundation in partnership with the NoVo Foundation in 2006, the global Girl Effect 'movement' consists of hundreds of projects and campaigns targeting adolescent girls across the poorest countries. The Nike Foundation was set up by Nike Inc. in 2004 , to fund development projects specifically targeting adolescent girls in the poorest countries, in the areas of education, sport and health.

As discussed earlier, what Roy (2010) terms 'Millennial

Development' has been shaped by a range of agendas and priorities including those of the World Bank, IMF and other agencies of global governance, but also critiques of these organisations and their neoliberal agendas developed via activist struggle against anticapitalism. 'Millennial development' also relies 'on the modern, western, self who is not only aware of poverty's devastating impact but is empowered to act upon it in responsible ways' (2010: 12). Various campaigns (including for example, the Pampers UNICEF campaign to fund vaccinations against neonatal tetanus) establish connections between buying commercial products and 'lifesaving' rely on this all-knowing empowered subject, revealing a complex web of actions, intentions and commitments to 'poverty alleviation'. 
The Girl Effect is defined as 'the unique potential of 600 million adolescent girls to end poverty for themselves and the world' (Girl Effect website). The website is littered with statistical data disaggregating the impact of poverty on girls as well as toolkits to support awareness and fund raising. The global appeal of the Girl Effect lies in the use of Nike's branding expertise and creative repertoire which has produced memorable catchphrases and directives: 'Send her to school. Help fight her legal case. Give her a microloan. Start making a difference. Start the girl effect' (Girl Effect website). Grouped together, the directives act as a metaphor for social change. They invoke a 'can do' philosophy which targets both consumer as potential investor/donor and the object of scrutiny, the girl, whose assumed propensity for labour makes her an ideal subject for investment (Wilson 2011). As Wilson argues, the consumer is empowered by being made to feel that with the click of a mouse they can change the future for a girl and through their action, start a 'ripple' effect that will lead to the end of poverty. Two alternative scenarios are presented on the Girl Effect website that have the sense of empowering the consumer by inviting them to decide the fate of 'the girl':

A. SHE GETS A CHANCE: she gets educated; she stays healthy; marries when she chooses; raises a family. As a result, 'she has the opportunity to raise the standard of living for herself and her family'

B. NONE OF THIS HAPPENS: she is illiterate; married off; is isolated; is pregnant; vulnerable to HIV. As a result 'she and her family are stuck in a cycle of poverty'. (Girl Effect website)

These two scenarios are carried through a range of YouTube videos. Eight short video case-studies of around 2 minutes in length, feature girls who tread one or other of the two paths referred to above. For example, Kidan from Ethiopia, wants to be a doctor, but 
her mother says 'she cannot. She is engaged. She doesn't even know about it. This will give us cattle'. The following statistics appear at the end of the video: $60 \%$ of girls are married before the age of 18 . Pregnancy is the leading cause of death for girls aged 15-

19. Shumi, from Bangladesh on the other hand, featured in another video, lives in a village where girls do not go to school. However, with the support of the Nike Foundation, Shumi has been able to pay her school fees and with a microloan of $\$ 37$ has opened up her own hairdressing business. Shumi comments, 'there are lots of parents who won't let girls go to school. I would tell big companies and big people if they could help a poor person like me that a person can do good in the world'. This plays on the dominant stereotypes of dependency and the undeserving poor which Shumi, by making the most of the investment in education and her business, firmly expels. In another video, we are told how a 'microloan of $\$ 60$ turned into a cow' and helped Sanchita, from Sri Lanka, 'to unleash the Girl Effect'. These themes are further developed in three popular videos which have acquired a combined total of almost 4 million hits at the time of writing.

I dare you (2006: 2.31 mins) directly challenges established racialised conceptions of girls in the global South as helpless and dependent victims. Girls of various ethnic backgrounds stare defiantly into the camera as the (African female) voiceover throws out a challenge to the viewer. 'I dare you to look at me and see a statistic, a tragedy, child bride', 'more than a poster for your cause', 'a promise you won't keep'. 'I dare you to look at me and see not a burden, not an object but the answer'. The invitation invokes familiar racialised, sexualised and gendered stereotypes of poor girls as the helpless, passive, burdensome victim of western aid. But the video proceeds to present girls as not the problem but the answer that stands 'right in front of' the viewer. 'Dare to see this girl. Count her. Invest in her. Advocate for her'. She is, the viewer is 
told 'the most powerful force of change on the planet'. The video ends with a series of statistics which highlight gender gaps in development and which serve to construct girls in the global South as capable but neglected both by foreign aid and by patriarchal cultures within their societies. For example, 'if $10 \%$ more girls go to school, the economy grows by 3\%', '99.4\% of international aid does not reach her'; 'When an educated girl earns an income she invests $90 \%$ of it in her family compared to $35 \%$ for a boy'.

Girl effect (2008: 2.23 mins) features only capitalised words against a white background. There are no images or voiceovers. It begins:

THE WORLD IS A MESS. HIV/AIDS. POVERTY. AIDS. HUNGER. WAR. WHAT IF THERE WAS A SOLUTION. WOULD YOU KNOW IT IF YOU SAW IT?

ITS [DRAMATIC PAUSE] A GIRL!

IMAGINE A GIRL LIVING IN POVERTY, NO REALLY, GO AHEAD, REALLY, IMAGINE HER.

As Wilson (2011) has argued in her analysis of this video alongside a set of advertising campaigns, including Oxfam unwrapped[2], and Divine chocolate[3], the absence of images or voiceovers could be read to signify an intention to avoid the perpetuation of the racialised stereotypes that are often found in more explicit photographic images and texts used by NGOs of girls in the global South. However, the invitation to the viewer to 'imagine a girl in poverty', to 'go ahead' and 'really, imagine her' paradoxically, invites these established racialised stereotypes to be drawn on in constructing the girl living in poverty.

The middle sequence of the video also perpetuates dominant racialised stereotypes of poor women as helpless victims as the GIRL surrounded by FLIES, is then squashed by BABY, HUSBAND, HUNGER and HIV. The invitation to 'pretend that you can fix this' exhorts the viewer into solving the girl's poverty as they are invited to donate to 
the campaign and to spread its message. This will 'put her in a school uniform' and 'give her a microloan to buy a cow', which pretty soon 'turns into a herd and turns her into a respected entrepreneur within her village', and the viewer as a powerful initiator of change. A string of words: GIRLS SCHOOL COWS DOLLARS BUSINESS CELAN H2O SOCIAL CHANGE STRONGER ECONOMY is flashed up in quick succession against the backcloth of dramatic and uplifting music forming a chain sequence that serves to highlight the significant potential of microfinance. Through the text the potential investor is empowered to make a difference and 'save' not only the girl but 600 million others like her.

There are no voiceovers in the third and latest Girl Effect video Clock is ticking (2010: 3.05) but the animated figure of a girl, curiously sporting quite developed breasts, appears as a black spot and grows against the backcloth of a ticking clock. The clock stops at 12 . Again using capitalised words, the video coveys the message that time is running for the girl whose 'future is out of her control'. She falls into a whirlpool of sexualised poverty: 'She is married at 14, pregnant at 15 and might have to sell her body to support her family; not the life you imagined for a 12 year old'. The girl is chased endlessly by a pair of extending black arms (poverty) and a single red arm (HIV) which captures her when she is forced to 'sell her body to support her family'. The viewer is exhorted into solving the problem and initiating an alternative course of action along path $A$ : 'She stays in school and uses her education to earn a living; Escapes poverty; She can marry and have children when she's ready and now she's calling the shots'.

The racialised and sexualised representation of the girl across these videos relies on and reworks colonial stereotypes of black women as overtly sexual and rapacious and in need of fertility control. Indeed, family planning and fertility control, presented through a discourse of 'rights' and 'choice' have been actively promoted by high profile 
campaigners such as Melinda Gates, in addition to being embedded within development campaigns such as the Girl Effect. However well-intentioned and passionately conveyed, the focus on fertility control tends to reinforce the idea of population control as a solution to poverty. Harcourt (2011) questions the genesis and validity of such neo-Malthusian population arguments and their positioning of poor women negatively in relation to population growth, as breeders of poverty and violence and environmental destruction. Controlling their fertility becomes the 'magic bullet solution'. This focused gaze on the reproductive body also obscures structural inequalities and by positioning poor men as sexual oppressors of girls and women, decontextualises gender relations. Marchand (2009) argues that the current gender and development field - by essentialising and universalising the experiences of all girls living in poverty, shifts attention away from the ways in which gender relations permeate all sectors and levels of society and are embedded in local histories, practices and discourses. Such practices and discourses produce locally constructed masculinities and femininities which also need to be analysed in the context of local economic, political and social contexts. It is perhaps also worth noting here, that the UK's version of Girl Effect, 'Girl Hub', an initiative that was jointly funded by the Nike Foundation and the Department for International Development, was criticised in 2012 by the development watchdog, the Independent Commission for Aid Impact, for failing to have a child protection policy in place. So, apparently, while the Girl Effect campaign relies on promoting a message of girls 'at risk' of sexual exploitation in their home countries, girls under the age of 16 have been regularly photographed and taken on trips abroad to promote Girl Effect, without the protection that is afforded to girls in Western nations. This apparently innocent oversight, is particularly telling of how girls' vital role in spreading the message of the campaign has taken 
precedence over the safety of individual girls - that is, girls have been instrumentalised as 'champions' for the cause (Provost 2012).

The construction in development campaigns of girls as more capable than boys and men but constrained by men, their cultures and by poverty; as defiant but in need of assistance from western donors and investors, also produces contradictory representations of girls. However, the conflation of empowerment and the 'needs of the global economy' fixes girls as instruments of social change. Bexell (2010) argues that there is a tension between the representation of the girl in need of protection and help, and the image of the competent capable girl/woman who runs the family better than men. This tension coheres with a shift in development rationality from one where the state has an obligation to help to the poor, to one in which individuals are responsibilised, in this case, as women entrepreneurs with cultural propensities to invest wisely and look after their families and communities (Rankin 2001: 20). Girls are depicted as 'the engines for recovery' according to the Girl Effect and the World Bank (Bexell 2010: 16) with the implication that their propensity for hard work, and their 'safe hands' when it comes to investment, will pull the world out of the global financial crisis and reinvigorate growth (ibid). At the same, time neoliberal measures invariably involving microfinance are presented as the only way out of the current poverty and deprivation for many of the girls and women in the global South. Microfinance has gained prominence since the 1980s as a -bottom-up-solution to support poverty alleviation. It encompasses a range of financial services aimed at offering credit to poor populations who are excluded from the normal system of credit. However, feminists (Goetz and Gupta 1996; Elyachar 2005; Jakimow and Kilby 2006; Rankin 2008; Roy 2010) and Marxists (Harvey 2011) have critiqued microfinance for its tendency to generate new forms of dominance over women under the guise of financial empowerment. Women may be the 
recipients of microfinance but it is not always clear that they are the main beneficiaries of it. In some cases, as Goetz and Gupta (1996) report, men control the investments leaving women borrowers to bear the liability for repayment. In many cases this has led to women recycling debt at much higher rates than the original investments (Glazer 2010). Studies have also revealed how women have been strategically targeted by Banks for microfinance, because they are assumed to be more easily traceable, more disciplined and very likely to pay back their loans (Rahman 1999). Roy (2010), defines microfinance as poverty capital (see also Rankin 2001) - a frontier where finance capital and development capital 'merge and collaborate such that new subjects of development are identified and new territories of investment are opened up and consolidated' (2010: 29-30). Not only does this represent new potential markets for Microfinance Institutions at a time when the global financial crisis and the debt crisis has closed down opportunities in the global North, but micro lending also produces new neoliberal subjectivities with women working more industriously to pay back their loans.

At the same time that neoliberal measures invariably involving micro lending are presented as the only way out of the current poverty and deprivation faced by many of girls and women in the global South, research on transformative movements in Latin America and the South (see for example, Baiocchi et al. 2012) reports a number of positive alternative initiatives that have followed on from the failure of the 'neoliberal experiment'. Within the last decade, there have been a growing number of transformative initiatives outside the context of neoliberalism in various Latin American countries, in particular in Brazil, Bolivia, Equador, Venezuela and Cuba. For instance, the Bank of the South has been introduced by regional powers as an alternative to the policy of the International Monetary Fund (IMF). The Bank of the South promotes a new financial 
architecture for the region through which the countries can finance their own projects. Another example is the initiative Operaci-n Milagro (Operation Miracle) first introduced in Cuba and then expanded to Venezuela and Bolivia. Through this initiative thousands of medical doctors, from poorer backgrounds, have been trained in medical schools in Cuba and Venezuela, and then sent to other parts of Latin America where there is an acute need for basic medical help.

While this is perhaps too early to assess the impact of these initiatives on girls and women in economic, political and social terms, there are many examples suggesting that women and girls have been at the forefront of such campaigns, and exercising a different sort of agency and empowerment to that conceptualised in current neoliberal development. The Zapatista female commanders in Mexico and the mothers and grandmothers of the Plaza de Mayo in Argentina are just two examples. Women also led the national movement for the defence of President Ch-vez in Venezuela during the two-day reign of right-wing hardliner Pedro Carmona following the US-supported coup on 11 April 2002.

The initiatives reported by Baiocchi et al. (2012) are small community-oriented non-commercial enterprises which to date, are said to have yielded positive results in metrics terms. According to UNESCO, illiteracy has all but been eliminated in Venezuela and significantly declined in Bolivia. In Brazil, unemployment reached a historical low of six per cent in 2011 . The number of families living in extreme poverty has been halved and 28 million people have been pulled out of poverty from 2003-2010. The 2010 national census shows that from 2000, the poorest 50 per cent of people in Brazil increased their income by 68 per cent, while the richest ten per cent only increased theirs by ten per cent. This has substantially increased massive upward social mobility. Thirty-eight million people have moved into income category C ('lower middle class') of 
the national statistics, and approximately half of the population belongs to this category. Social strata which was previously excluded from the mass consumption society of modern capitalism have now become economically 'empowered' (Baiocchi et al. 2012).

\section{Conclusion}

This paper has analysed the contradictory representations of girls and women in development campaigns and promotional materials alongside policy statements from the World Bank. Drawing on theoretical debates around gender mainstreaming and critical accounts of global neoliberal restructuring, I have argued that the notions of empowerment and agency embedded in the discourse of 'smart economics' represent a 'deep' neoliberalisation of development policy rather than a shift to a more caring kind of neoliberal development agenda. Girls and women have come to prominence in neoliberal development agendas at a time of renewed crisis since the mid-2000s as instruments of economic growth and efficiency.

I have also argued the constructions of girls, through neoliberal discourses of empowerment, as ideal investment potential, reproduces contradictory representations. Colonial representations of girls and women as overtly sexualised, culturally constrained and in need of 'saving' from westerners, are re-worked and reproduced through current discourses of neoliberal development while consumers of the messages are exhorted into solving global poverty through benevolent individualism and altruism. These contradictory representations position girls as good investment potential but it is the agency of the viewer/consumer rather than the girls' that is invoked by the texts. Campaigns such as the Girl Effect, however well-intentioned, serve to de-contextualise gender relations and depoliticise poverty, through emphasis on cultural constraints and the universal sexual oppression of girls and women in the global 
South. In doing so, representations of girls in development literature, divert attention away from the structural causes of inequalities and relations of exploitation and privilege. Indeed, the texts work by reminding potential donors who may be living through austerity politics in the global North that things are really not that bad after all.

Notes

1 The terms global North and global South are used to refer to two broad geopolitical groupings with the North representing richer 'more advanced' economies and the South referring to the regions that were characterised in the 1970s as 'Third World' nations. However, it is important to note that since the beginning of the 2008 global economic crisis the previously sharply emphasised lines between the Global North and Global South have disappeared to a large extent. While the Global North still generally represents the economically developed societies of Europe, North America, Japan, Australia amongst others, the term Global South, in addition to including still developing economies of Africa, Southeast Asia and Latin America, also includes what are now a group of fast growing 'emerging economies' of India, China, Brazil, Mexico, South Africa and Turkey amongst others.

2 Oxfam Unwrapped was launched by Oxfam in 2004. With its catchphrase 'Change the present, change the world', the campaign encourages charitable donations as an alternative gift idea in place of presents. Family and friends receive a card while the actual gift, ranging from condoms, to goats or trees, goes to people in the developing world who need it most. www.oxfamunwrapped.com

${ }^{3}$ Divine Chocolate, a leading Fairtrade brand in the UK, launched its 'Divine makes you feel good' campaign in 2006. This campaign, 
which appeared in national supplements, lifestyle and ethical media, featured full page magazine shots of young women from the Kuapa community posing happily with pieces of chocolate in what are clearly breaks from work. Wilson (2011) argues that the images present young women as happy and industrious in their work and as a strong investment potential.

References

AMIN, S. (2010) Ending the crisis of capitalism or ending capitalism?. Oxford: Pambazuka Press.

BAIOCCHI, G., Braathen, E. \& Texeira, A. C. (2012) 'Transformation institutionalized? Making sense of participatory democracy in the Lula Era', in Stokke, C. and Thornquist, O. (Eds), Democratization in the global South: The importance of transformative politics. London: Palgrave McMillan.

$<$ http://www.inesc.org.br/news/2012/april/transformationinstitutionalized-new-essay-on-the-lula-era $>$.

BATLIWALA, S. \& Dhanraj, D. ( 2004) 'Gender myths that instrumentalise women: A view from the Indian frontline', IDS Bulletin, 35(4) p. 11-18.

BEDFORD, K. (2012) Gender WDR Limits, gaps, and fudges, Bretton Woods Project, 8 February.

$<$ http://www.brettonwoodsproject.org/art-569646 $>$

BEXELL, M. (2010) 'Global governance, legitimacy and gender'. UNBusiness Partnerships For Women's Rights Paper for the SGIR conference, Stockholm, September 2010, Section Democratic Governance and International Institutions Panel Transnational Governance and Democracy. $<$ http://stockholm.sgir.eu/uploads/Bexell\%20SGIR\%202010.pdf > 
BRENNER, N., \& Theodore, N. (2002) 'Cities and the geographies of "actually existing neoliberalism"',-Antipode,-34(3) p. 349-379

CAMMACK, P. (2004) 'What the World Bank means by poverty reduction, and why it matters', New Political Economy, 9(2) p. 189211.

CHANT, S. (2006) 'Contributions of a gender perspective to the analysis of poverty', in Jaquette, J. and Summerfiled, G. (Eds), Women and gender equity in development theory and practice: Institutions, resources, and mobilization (pp. 87-106). London: Duke University Press.

CHANT, S. (2012) Global Social Policy: The disappearing of 'smart economics'? The-World Development Report 2012 on Gender Equality. Some concerns about the preparatory process and the prospects for paradigm change-August Vol. 12, No. 2, p. 198-218.

CHANT, S., \& Gutmann, M. C. (2002). 'Men-streaming'gender? Questions for gender and development policy in the twenty-first century.-Progress in Development Studies,-2(4), 269-282.

CORNWALL, A., \& Brock, K. (2005) 'What do buzzwords do for development policy? A critical look at "participation", "empowerment" and "poverty reduction"', Third World Quarterly, 26 p. 1043-1060.

COUNCIL OF EUROPE (1998)- Gender mainstreaming: conceptual framework, methodology and presentation of good practice: final report of activities of the Group of Specialists on Mainstreaming (EG-S-MS). Council of Europe.

ELSON, D. (1991) Male bias in macro-economics: the case of structural adjustment.-Male bias in the development process (pp. 164-190). Manchester: Manchester University Press. 
ELYACHAR, J. (2005) Markets of dispossession: NGOs, economic development, and the state in Cairo. Durham: Duke University Press.

ESCOBAR, A. (2010) Ecountering development. Princeton: Princeton University Press.

EYBEN, and Napier-Moore, R. (2008) 'Conceptualising women's empowerment in international development agencies' pathways of women's empowerment in international development agencies', Global Hub working paper.

$<$ http://www.pathwaysofempowerment.org/International_Developm ent_Agencies_working_paper_draft.pdf $>$

EYBEN, R. \& Napier-Moore, R. (2009) 'Choosing words with care? Shifting meanings of women's empowerment in international development', Third World Quarterly,-30(2) p. 285-300.

FERGUSON, L. (2010) 'Interrogating 'Gender' in Development Policy and Practice', International Feminist Journal of Politics, 12(1) p. 324.

FRANCIS, B. \& Skelton, C. (2008) '"The self-made self": Analysing the potential contribution to the field of gender and education of theories that disembed selfhood',-Discourse: Studies in the Cultural Politics of Education,-29(3), p. 311-323.

FREY, R., Hartmann, J., Heimann, A., Kugler, T., Nordt, S., \& Smykalla, S. (2006), 'Gender-Manifest [Gender manifesto]', Switchboard (August-September), 177 p. 4-7. $<$ www.gendermainstreaming.org $>$ (Berlin).

GLAZER, S. (2010) Evaluating microfinance: Do small loans for poor entrepreneurs help end poverty? New York: CQ Press. 
GOETZ, A. M. and Gupta, R. S. (1996) 'Who takes the credit? Gender, power, and control over loan use in rural credit programs in Bangladesh', World Development 2, 24(1) p. 45-63.

HARCOURT, W. (2011) 'Editorial note: at the heart of body politics',Development, 44(3) p. 3-5.

HARVEY, D. (2011) The enigma of capital: and the crises of capitalism. London: Profile Books.

HARVEY, D. (2005) A brief history of neoliberalism. Oxford: Oxford University Press.

HAYHURST, L. (2011) 'Corporatising sport, gender and development: Postcolonial IR feminisms, transnational private governance and global corporate social engagement', Third World Quarterly 32(3) p. 531-549.

JACKSON, C., Paechter, C. \& Renold, E. (2010) Girls and education 316: Continuing concerns, new agendas. Maidenhead, UK: Open University Press.

JAKIMOW, T. \& Kilby, P. (2006). 'Empowering women a critique of the blueprint for self-help groups in India',-Indian Journal of Gender Studies,-13(3), p. 375-400.

JESSOP, B. (2002). 'Liberalism, neoliberalism, and urban governance: A state-theoretical perspective',- Antipode,-34(3) p. 452-472.

KABEER, N. (1994) Reversed realities: Gender hierarchies in development thought. London: Verso Books.

KABEER, N. (2003) Gender mainstreaming in poverty eradication and the millennium development goals: $A$ handbook for policy-makers and other stakeholders, London: Commonwealth Secretariat. 
MARCHAND, M. (2009) 'The future of gender and development after 9/11: Insights from postcolonial feminism and transnationalism', Third world Quarterly, 30(5) p. 921-935.

MCROBBIE, A. (2009) The aftermath of feminism: Gender, culture and social change. London: Sage.

MOHANTY, C. T, (1988) 'Under western eyes: Feminist scholarship and colonial discourses', Boundary 2, 2(3) p. 333-358.

MOHANTY, C. T. (2002) 'Under western eyes revisited: Feminist solidarity through anticapitalist struggles'. Signs: Journal of Women in Culture and Society, 28(2) p. 499-535.

MOSEDALE, S. (2005) 'Assessing women's empowerment: towards a conceptual framework', Journal of International Development 17(2) p. 243-257.

PECK, J. \& Tickell, A. (2002) 'Neoliberalizing space', Antipode,-34(3) p. 380-404.

PROVOST, C. (2012) Watchdog raises questions over impact of Nike's Girl Hub, Guardian, 4 March.

RADCLIFFE, S. (2006). 'Development and geography: Gendered subjects in development processes and interventions',--Progress in Human Geography, 30(4) p. 524-532.

RAHMAN, A. (1999).- Women and microcredit in rural Bangladesh: anthropological study of the rhetoric and realities of Grameen Bank lending. Colarado: Westview Press.

RANKIN, K. N. (2001) 'Governing development: Neoliberalism, microcredit, and rational economic woman',-Economy and Society,30(1) p.18-37. 
RANKIN, K. N. (2008) 'Manufacturing rural finance in Asia: Institutional assemblages, market societies, entrepreneurial subjects',-Geoforum,-39(6) p. 1965-1977.

RINGROSE, J. (2012) Postfeminist education?: Girls and the sexual politics of schooling. London: Routledge

ROY, A. (2010) Poverty capital: Microfinance and the making of development. London: Routledge.

ROY, A. (2007).-Calcutta requiem: Gender and the politics of poverty. Delhi: Pearson Education India.

SAID, E. (1993) Culture and imperialism. London: Chatto \& Windus.

SARDENBERG, C. (2007) 'Back to women? Translations, resignifications and myths of gender in policy and practice in Brazil', in Cornwall, A., Harrison, E. and Whitehead, A. (Eds), Feminisms in development: Contradictions, contestations and challenges (pp. 4864). New York: Palgrave Macmillian.

SEN, A. K. (1999) Development as freedom. Oxford: Oxford University Press.

SPIVAK, G. C. (1999). A critique of postcolonial reason: Toward a history of the vanishing present. Harvard University Press.

SPIVAK, G. C. (2002). -Resident alien?-, in Goldberg, D. T. and Quayson, A. (Eds.),-Relocating postcolonialism. Oxford: Blackwell. pp. 47-65.

STIGLITZ, J. E. (1998) Towards a new paradigm for development. United Nations Conference on Trade and Development.

WALBY, S. (2002). 'Feminism in a global era',-Economy and Society,(3) 4 p. 533-557. 
WALBY, S. (2005). 'Gender mainstreaming: Productive tensions in theory and practice',-Social Politics: International Studies in Gender, State \& Society, 12(3) p. 321-343.

WILSON, K. (2011) '"Race", gender and neoliberalism: changing visual representations in development', Third World Quarterly, 32(2) p. 315-331.

WOODFORD-BERGER, P. (2004) 'Gender mainstreaming: what is it (about) and should we continue doing it?' IDS Bulletin, 35(4) p. 6572.

WORLD Bank (1990)- World Development Report 1990: Poverty. Washington DC:World Bank.

WORLD Bank (2006) Gender Equality as Smart Economics: A World Bank Group Gender Action Plan (Fiscal years 2007-10). Washington DC: World Bank.

WORLD Bank (2007) Gender Equality as Smart Economics: A World Bank Group Action Plan. Washington DC: World Bank.

WORLD Bank (2008) World Bank Press release 'Adolescent girls'. $<$ http://siteresources.worldbank.org/INTECAREGTOPGENDER/Resou rces/AdolescentGirls08PressRelease1.pdf>

WORLD Bank (2012) World Development Report: Gender Equality. Washington DC: World Bank. 